\title{
Генерация суперконтинуума в канальном волноводе, записанном пучком фемтосекундного лазера в теллуритном стекле
}

\author{
А.Г. Охримчук ${ }^{1,2, *}$, М.П. Смаев ${ }^{1}$, А.Д. Прямиков ${ }^{1,2}$, Ю.П. Яценко ${ }^{2}$, \\ В.В. Лихов ${ }^{1}$, С.Е. Моторин ${ }^{3}$, В.В. Дорофеев ${ }^{3}$ \\ ${ }^{1}$ Российский химико-технологический университет, \\ ${ }^{2}$ Научный Центр Волоконной Оптики РАН, \\ ${ }^{3}$ Иститут химии высокочистых вещееств РАН. \\ *E-mail: a.okhrim@yandex.ru
}

DOI:10.31868/RFL2018.176-177

Востребованность ярких широкополосных источников света среднего ИК стимулирует работы по созданию генераторов суперконтинуума на основе мягких стёкол, прозрачных в этом диапазоне спектра. В последнее время этом направлении исследований значительный прогресс был достигнут в генераторах на основе волоконных световодов [1,2]. Однако в традиционной технологии изготовления волокон из мягких стёкол по методу штабик-трубка всегда присутствует опасность неконтролируемого загрязнения границы сердцевинаоболочка такими неконтролируемыми примесями, как гидроксильные группы, обладающие мощным поглощением в среднем ИК и препятствующие развитию суперконтинуума. Чтобы решить эти технологические проблемы, мы предлагаем альтернативную технологию изготовления волноводов на основе мягких стёкол, а именно, прямую лазерную запись в объёме стекла, которая полностью исключает любые загрязнения в области волновода в процессе его формирования. Кроме того, из-за хрупкости теллуритного стекла существует проблема механической прочности изготовленных из него волоконных световодов. Объёмный стеклянный элемент, содержащий волновод в своём объёме, более прочен и проще в эксплуатации по сравнению с волоконным световодом.

Волновод был записан пучком фемтосекундного лазера на длине волны 1030 нм при частоте повторения импульсов $180 \mathrm{kHz}$, длительности и энергии импульса 180 fs и 65 nJ соответственно в объёме пластинки высокочистого стекла $70 \mathrm{TeO}_{2}-22 \mathrm{WO}_{3}-8 \mathrm{Bi}_{2} \mathrm{O}_{3}$. Были записаны 32 трека пониженного показателя преломления (на 0,008), которые сформировали оболочку волновода, a сердцевина осталась немодифицированной областью стекла (Рис.1а). Измерена дисперсия групповой скорости света в исследуемом стекле в области длин волн 1,2-2,3 км. Нуль дисперсии оказался на длине волны 2120 нм.

Обнаружено, что размер фундаментальной моды увеличивается с увеличением длины волны с резким возрастанием в области 1900 нм, что мы связываем с увеличением утечки моды через оболочку с увеличением длины волны. Исследована генерация суперконтинуума в волноводе при заведении в него пучка фемтосекундного параметрического усилителя с частотой повторения и длительностью импульсов $9 \mathrm{kHz}$ и 80-200 fs соответственно, и с центральной длиной волны в диапазоне 1600-2200 нм. Наиболее широкий спектр на выходе из волновода (1800-2600 нм по уровню в -20 dB) был получен при накачке на длине волны 1870 нм импульсами с энергией 400 nJ (Рис.1б). Волноводные потери на этой длине волны составили $0,43 \mathrm{~dB} / \mathrm{cm}$. Мы полагаем, что оптимальная длина волны накачки на 1870 нм обусловлена компромиссом 
между увеличением потерь на вытекание моды при увеличении длины волны и уменьшением дисперсионного расплывания импульса в области волн нулевой дисперсии.

Наблюдаемый спектр хорошо моделируется численным расчётом нелинейного распространения моды в помощью обобщенного нелинейного уравнения Шреденгера. Установлено, что сравнимый вклад в уширение спектра дают Керровская нелинейность и комбинационное рассеяние.

Таким образом, продемонстрирована перспективность волноводов, записанных фемтосекундым лазером в теллуритном стекле, для генерации суперконтинуума, но для продвижения суперконтинуума далее в сердний ИК необходимо совершенствовать архитектуру волновода с целью уменьшения потерь на вытекание моды.

(a)

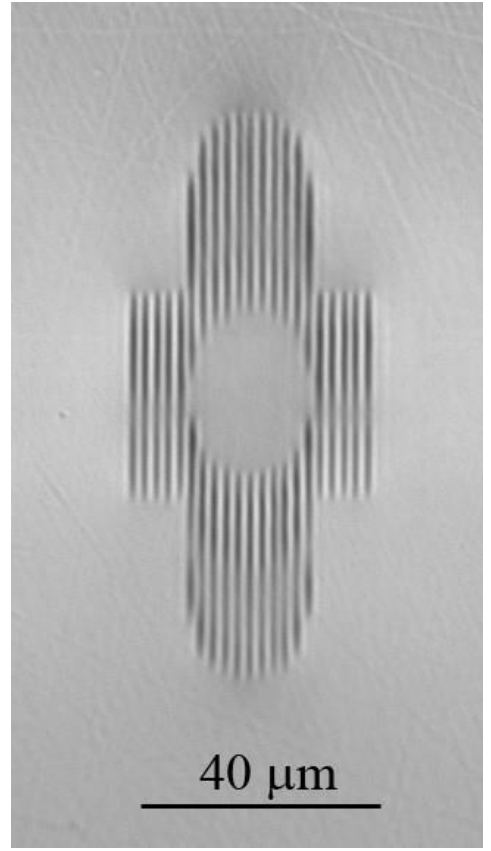

(b)

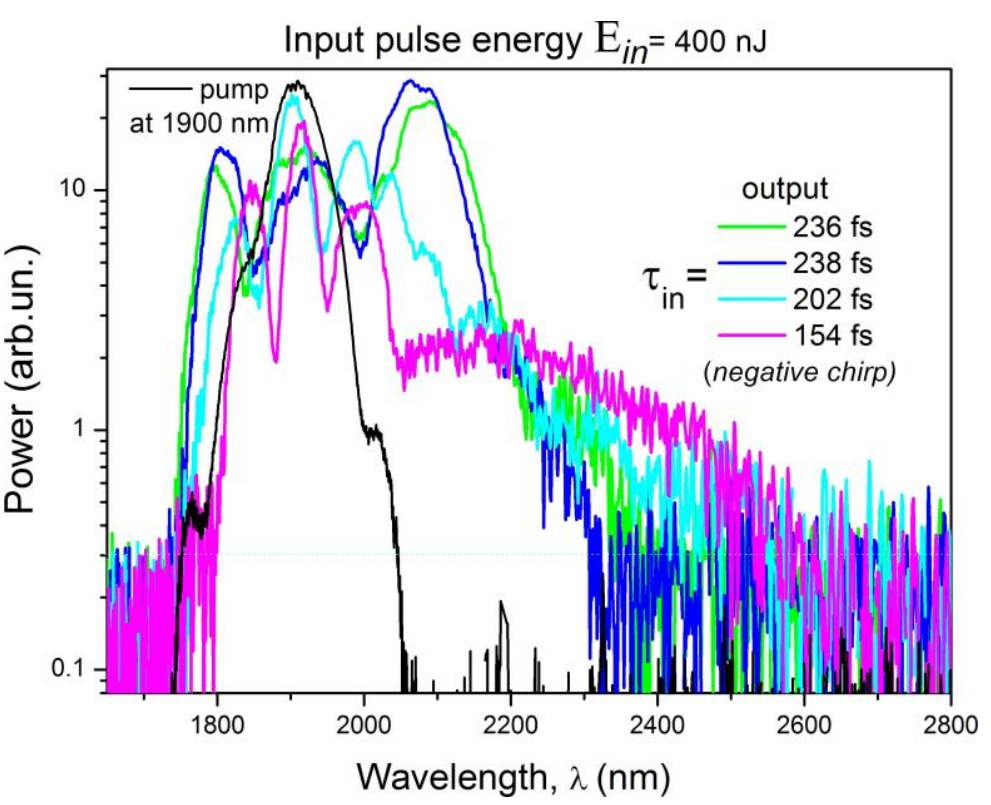

Рис.1. а) Изображение торца волновода с оболочкой пониженного показателя преломления; б) спектры излучения на выходе волновода при накачке на длине волны 1870 нм чирпированными фемтосекундными импульсами различной длительности, указанными на рисунке, и энергией в $400 \mathrm{~nJ}$.

Исследования поддержаны РНФ, грант \#18-19-00733.

\section{Литература}

[1] Yi Yu, et al, Opt. Mater. Express 3, 1075-1086 (2013).

[2] R. A. Martinez, et al, Opt. Lett. 43, 296-299 (2018).

[3] M.P. Smayev, et al, Journal of Non-crystalline Solids, 480, 100- 106 (2018). 